\title{
Teaching Video NeuroImages: Optic Ataxia as the Presenting Sign of the Heidenhain Variant of Creutzfeldt-Jakob Disease
}

Shi-Lin Yang, MD, Xiang Han, MD,* and Qiang Dong, MD*

Neurology ${ }^{\circledR}$ 2021;97:e326-e328. doi:10.1212/WNL.0000000000012057

A 59-year-old woman presented with subacute onset of hand clumsiness followed by memory loss. She reported difficulty reaching for objects, although she could see them. Examination (video) showed optic ataxia, visual acuity of 20/30 OU, intact visual field, and near-normal finger-to-nose test. Hyperintense signals in the left temporo-parieto-occipital cortex in diffusion-weighted MRI, periodic triphasic complexes in EEG (figure), and elevated t-tau in CSF suggested the Heidenhain variant of Creutzfeldt-Jakob disease. ${ }^{1}$ The patient received supportive care and progressed to akinetic mutism. Optic ataxia-inaccuracy of visually guided arm movements - is a visuomotor disorder associated with lesions involving the posterior parietal cortex. ${ }^{2}$

\section{Acknowledgment}

The authors thank Dr. Hong-Mei Liu for shooting the video.

\section{Study Funding}

No targeted funding reported.

\section{Disclosure}

The authors report no disclosures relevant to the manuscript. Go to Neurology.org/N for full disclosures.

\author{
Correspondence \\ Dr. Han \\ hansletter@fudan.edu.cnor \\ Dr. Dong \\ dong_qiang@fudan.edu.cn
}

\section{MORE ONLINE}

$\checkmark$ Video

$\rightarrow$ Teaching slides

links.lww.com/WNL/

B376

*These authors contributed equally to this work.

From the Department of Neurology, Huashan Hospital, Fudan University, Shanghai, China.

Go to Neurology.org/N for full disclosures. 


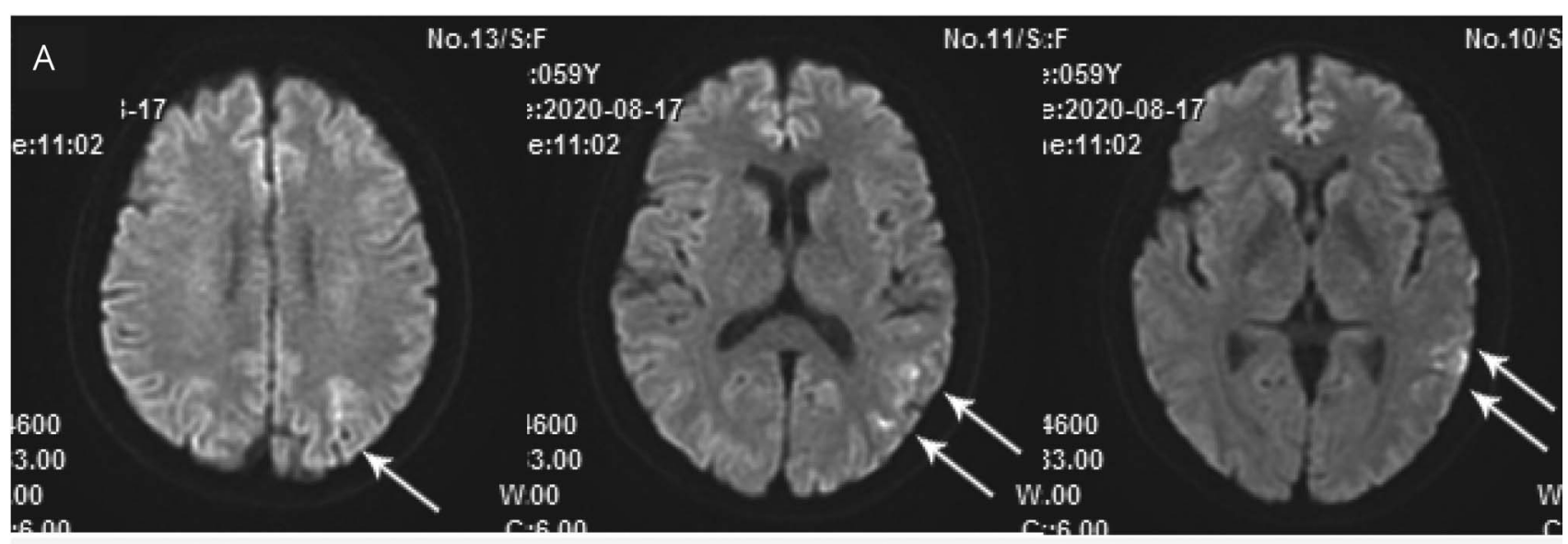

B

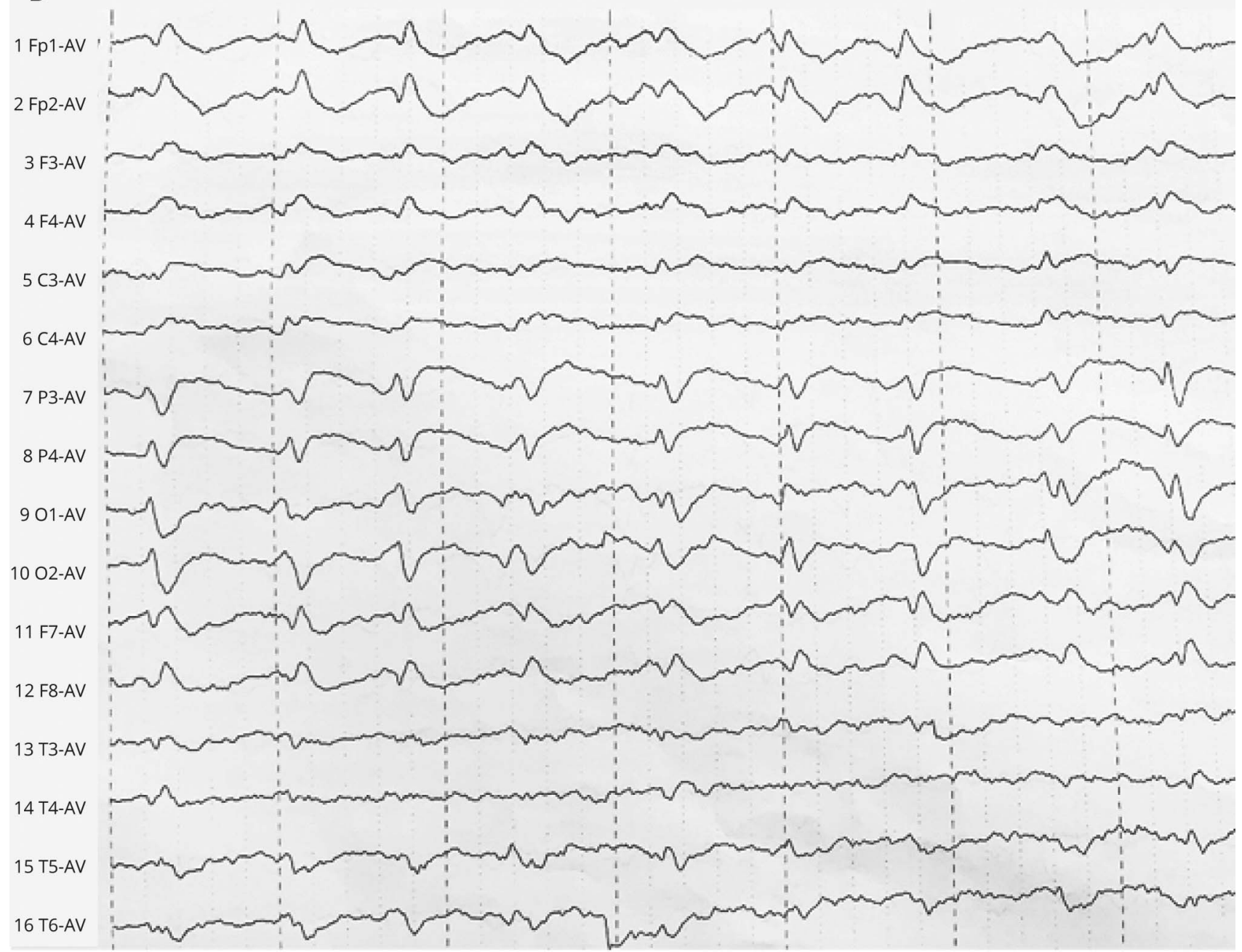

(A) Diffusion-weighted MRI shows hyperintense signals (arrows) in the left temporo-parieto-occipital cortex. (B) EEG shows periodic triphasic complexes at 1/s. 


\section{Appendix Authors}

\begin{tabular}{lll}
\hline Name & Location & Contribution \\
\hline $\begin{array}{l}\text { Shi-Lin } \\
\text { Yang, } \\
\text { MD }\end{array}$ & $\begin{array}{l}\text { Department of Neurology, } \\
\text { Huashan Hospital, Fudan } \\
\text { University, Shanghai, China }\end{array}$ & $\begin{array}{l}\text { Collection and } \\
\text { interpretation of data, } \\
\text { manuscript drafting }\end{array}$ \\
\hline $\begin{array}{l}\text { Xiang } \\
\text { Han, } \\
\text { MD }\end{array}$ & $\begin{array}{l}\text { Department of Neurology, } \\
\text { Huashan Hospital, Fudan }\end{array}$ & $\begin{array}{l}\text { Supervision, critical } \\
\text { revision of manuscript }\end{array}$ \\
\hline $\begin{array}{l}\text { Qiang } \\
\text { Dong, } \\
\text { MD }\end{array}$ & $\begin{array}{l}\text { Department of Neurology, } \\
\text { Huashan Hospital, Fudan }\end{array}$ & $\begin{array}{l}\text { Supervision, critical } \\
\text { revision of manuscript }\end{array}$ \\
\hline
\end{tabular}

\section{References}

1. Parker SE, Gujrati M, Pula JH, Zallek SN, Kattah JC. The Heidenhain variant of Creutzfeldt-Jakob disease: a case series. J Neuroophthalmol. 2014;34(1):4-9.

2. Perenin MT, Vighetto A. Optic ataxia: a specific disruption in visuomotor mechanisms: I: different aspects of the deficit in reaching for objects. Brain. 1988;111(pt 3) 643-674. 


\section{Neurology}

\section{Teaching Video NeuroImages: Optic Ataxia as the Presenting Sign of the Heidenhain Variant of Creutzfeldt-Jakob Disease \\ Shi-Lin Yang, Xiang Han and Qiang Dong \\ Neurology 2021;97;e326-e328 Published Online before print April 26, 2021}

DOI 10.1212/WNL.0000000000012057

This information is current as of April 26, 2021

Updated Information \& Services

References

Subspecialty Collections

Permissions \& Licensing

Reprints including high resolution figures, can be found at: http://n.neurology.org/content/97/3/e326.full

This article cites 2 articles, 0 of which you can access for free at: http://n.neurology.org/content/97/3/e326.full\#ref-list-1

This article, along with others on similar topics, appears in the following collection(s):

All Neuro-ophthalmology

http://n.neurology.org/cgi/collection/all_neuroophthalmology Clinical neurology examination

http://n.neurology.org/cgi/collection/clinical_neurology_examination Prion disease; see Infections/prion http://n.neurology.org/cgi/collection/prion_disease

Information about reproducing this article in parts (figures,tables) or in its entirety can be found online at:

http://www.neurology.org/about/about_the_journal\#permissions

Information about ordering reprints can be found online:

http://n.neurology.org/subscribers/advertise

Neurology ${ }^{\circledR}$ is the official journal of the American Academy of Neurology. Published continuously since 1951, it is now a weekly with 48 issues per year. Copyright @ 2021 American Academy of Neurology. All rights reserved. Print ISSN: 0028-3878. Online ISSN: 1526-632X.

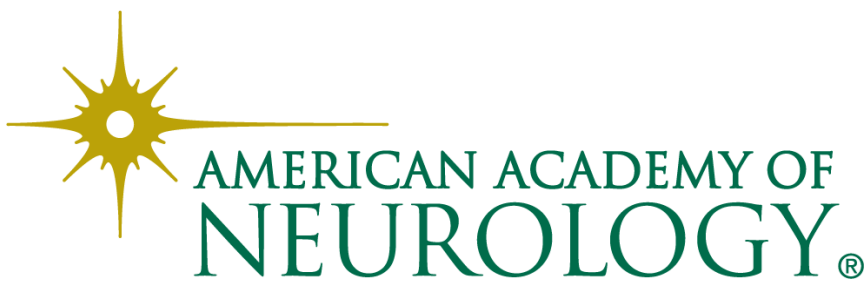

